\title{
Driving restriction in patients with cardiac implantable electronic devices: an overview of worldwide regulations
}

Jacopo F. Imberti, Marco Vitolo, Marco Proietti, Igor Diemberger, Matteo Ziacchi, Mauro Biffi \& Giuseppe Boriani

To cite this article: Jacopo F. Imberti, Marco Vitolo, Marco Proietti, Igor Diemberger, Matteo Ziacchi, Mauro Biffi \& Giuseppe Boriani (2020): Driving restriction in patients with cardiac implantable electronic devices: an overview of worldwide regulations, Expert Review of Medical Devices, DOI: 10.1080/17434440.2020.1742108

To link to this article: https://doi.org/10.1080/17434440.2020.1742108

Accepted author version posted online: 12 Mar 2020.

Submit your article to this journal $\widetilde{ }$

View related articles

View Crossmark data $\nearrow$ 
Publisher: Taylor \& Francis \& Informa UK Limited, trading as Taylor \& Francis Group

Journal: Expert Review of Medical Devices

DOI: $10.1080 / 17434440.2020 .1742108$

Review

\section{Driving restriction in patients with cardiac implantable electronic devices: an overview of worldwide regulations}

Jacopo F. Imberti ${ }^{1}$, Marco Vitolo $^{1}$, Marco Proietti $^{2}$, Igor Diemberger ${ }^{3}$, Matteo Ziacchi ${ }^{3}$, Mauro Biffi $^{3}$, Giuseppe Boriani ${ }^{1}$

${ }^{1}$ Cardiology Division, Department of Biomedical, Metabolic and Natural Sciences, University of Modena and Reggio Emilia, Policlinico di Modena, Modena, Italy

${ }^{2}$ Department of Clinical Sciences and Community Health, University of Milan and Geriatric Unit, Fondazione IRCCS Ca' Granda Ospedale Maggiore Policlinico, Milan, Italy

${ }^{3}$ Cardiology Unit, Department of Experimental, Diagnostic and Speciality Medicine, Sant'Orsola Hospital, University of Bologna, Bologna, Italy

Running title: Driving restrictions in patients with cardiac implantable electronic devices

\section{*Corresponding author:}

Giuseppe Boriani

Cardiology Division, Department of Biomedical, Metabolic and Neural Sciences , University of Modena and Reggio Emilia, Policlinico di Modena, Modena

Via del Pozzo 71, 41125 Modena

giuseppe.boriani@unimore.it

\section{Abstract}

Introduction: It is common belief that driving with an implantable cardioverter defibrillator (ICD)/pacemaker (PM) might be associated with sudden cardiac incapacitation, road traffic accidents and chance to harm to self and others. On the other hand, the ability to drive is highly valuable in the modern era, representing a cornerstone of daily living and employment. National regulations try to balance the right to drive of ICD/PM patients and the risk they pose to public safety, but rules for granting them a driving licence are considerably different 
worldwide. For the same subset of patients driving restrictions may vary between 1 week and 1 year depending on the local law.

Areas covered: In this article we systematically review driving restrictions in ICD/PM patients in 16 countries all over the world, highlighting their differences and analyzing data from the literature that underlie their formulation.

Expert opinion: Current regulations are mainly based on historical data that do not take into account improvements in ICD/PM technologies and driving environment, which have made driving with an ICD/PM is substantially safe. Newer studies and updated regulatory documents are warranted to set the best driving restrictions and reach homogeneity worldwide.

Keywords: driving licence, PM, pacemaker, ICD, implantable cardioverter defibrillator, CRT, cardiac implantable electronic device, sudden cardiac death

\section{Article highlights}

- Driving with a PM/ICD can be associated with sudden cardiac incapacitation, road traffic accidents and chance to harm to self an others. On the other hand, the ability to drive is a cornerstone of daily living and employment.

- Driving with a PM/ICD should be substantially safe for private drivers; on the contrary it is not for professional drivers.

- Considerable heterogeneity exists among driving restriction periods in PM/ICD patients worldwide.

- Adequately powered, well-designed, ad hoc trials are needed to properly assess the risk that ICD/PM patients pose to personal and public safety while driving and to draw up more homogeneous regulations all over the world.

\section{Introduction}

Implantable cardioverter defibrillators (ICD) and pacemakers (PM) are electronic devices indicated for the treatment of tachy and bradyarrhythmias. Despite their wellrecognized life-saving role (1-11), patients treated with these devices are at higher risk of sudden cardiac incapacitation (SCI) due to either delivery of device therapy or events related to the underlying heart disease (12-16). Sudden cardiac incapacitation is a fearful event, particularly while driving, since it can result in car accidents and harm to self and bystanders. On the other hand, the ability to drive is highly valuable in the modern era, representing a cornerstone of daily living and employment. Furthermore, driving restrictions imposed after ICD/PM implant have immediate detrimental effects on patients' quality of life and economic status (17-21). As a consequence, compliance to the driving ban is low and the majority of patients resume driving despite physician's unfavorable opinion $(15,16,22-31)$. Two studies specifically examined the factors correlated with the early resumption of driving. One study found that the 
importance of driving to maintain one's lifestyle, driving for necessity or social reasons, and being the primary driver in the family were predictors of low adherence to driving restrictions (23). The other study pointed out that younger, college educated men and those whose index arrhythmia was ventricular tachycardia were more prone to drive before the end of the restriction (30). These data highlights the negative effects of driving bans on patient's wellbeing and self-esteem. Therefore, physicians should provide an appropriate discharge education and schedule adequate follow-up visits to maximize patients' adherence to the driving restrictions, mitigating patients' and families' discomfort.

National regulatory agencies and cardiovascular societies published several documents trying to balance the right to drive of ICD/PM patients and the risk they pose to public safety. The duration of driving bans varies between countries and within the countries themselves, and is also influenced by the physicians' discretional evaluation (Table 1 and table 2). This heterogeneity sometimes leads to confusion and complaints by patients and uncertainty in decision making for physicians.

The aim of this article is to review driving restrictions in ICD/PM patients in different countries all over the world, highlighting their differences and analyzing data from the literature that brought to their formulation. Laws ruling the issuance of a driving licence in the broad scenario of "heart disease" patients (general cardiopathic population) vary between countries and are outside the object of this review.

\section{Definition of driving licence categories}

There are two main driving licence categories: private drivers (group 1) and professional (commercial) drivers (group 2). The definition of these two groups varies between countries on the basis of several parameters such as: number of kilometers driven per year, hours per year behind the wheel, weight of the vehicle and whether the vehicle is used to earn a living (Table 3). Drivers of Taxi Cabs, ambulances and other vehicles for professional purposes form an intermediate category, which usually falls in group 2, but can be locally determined.

\section{Sudden cardiac incapacitation (SCI) during driving and assessment of the risk of harm (RH) to patients and bystanders}

Arrhythmias and ICD therapies during driving may lead to syncope and sudden cardiac incapacitation (SCI), which in turn represents a risk to self and others. 
Data regarding the risk of driving in people with heart disease (with or without ICD) are essentially retrospective observational. Since 1992, the "Risk of Harm" (RH) formula (32) (33) is considered the major risk assessment tool to quantify the yearly risk posed by a driver with heart disease to self and other road users. The RH formula is based on the Ontario Road Safety Annual Report (34) and can be calculated as follows:

$$
\mathrm{RH}=\mathrm{TD} \times \mathrm{V} \times \mathrm{SCI} \times \mathrm{Ac}
$$

1) TD is the time spent driving, which is 0.04 ( 1 hour per day) for private drivers and 0.25 (6 hours per day) for professional drivers. 2) $V$ is a vehicle-specific constant. $V=0.28$ for family cars and $V=1$ for heavy trucks (involved in fewer road traffic accidents but with a higher rate of fatality) (34). 3) SCI is the yearly risk of sudden cardiac incapacitation (which can vary according with the underlying heart disease). Historically, the Canadian Cardiovascular Society and the Canadian Council of Motor Transport Administrators permitted to heavytruck drivers who experienced an acute myocardial infarction, are in functional class I, have a negative exercise stress test at 7 metabolic equivalents, have no documented ventricular arrhythmias and are at least 3 months post infarct to return to their occupation, and to people with the above reported characteristics was assigned a SCI value of 0.01 . 4) Ac is the probability that an episode of SCI will result in a fatal or injury-producing accident and is estimated to be 0.02 for all drivers.

Based on these assumptions, an annual RH of $0.005 \%(1: 20,000)$ was proposed as the cut-off value for issuing a driving licence. Of note, the $\mathrm{V}$ constant plays a major role in predicting the risk of harm. Notably, according to the RH formula, a private car driver with $22 \%$ yearly risk of SCI poses no greater risk than a heavy truck driver with $1 \%$ risk.

\section{ICD therapies while driving}

In ICD patients, shock rate while driving is low and, in general, the number of shocks causing car accidents is lower than the total number of shocks delivered.

Curtis et al. (24) analyzed the 452 responses of a survey sent to 742 U.S. physicians following-up patients with ICDs for secondary prevention. A total of 268 ICD shocks while driving were reported over a 12-years period. Thirty out of 268 (10.5\%) ICD discharges resulted in a car accident and 9/30 (30\%) accidents were fatal for 8 patients with a defibrillator and 1 passenger. Of note, in this study the estimated fatality rate for patients with defibrillator was significantly lower than that observed in the general population 
(7.5/100,000 patient-year for ICD drivers vs. 18.4/100,000 patient-years for the general population, p < 0.05). Trappe et al. (27) reported that 8/241 (5\%) ICD patients received a shock while driving over a follow-up period of 38 \pm 26 months and no ICD discharge resulted in a car accident. The AVID trial (16), comparing the survival benefit between antiarrhythmic drug therapy and ICD in secondary prevention patients, showed similar results: 8\% of patients with an ICD received a shock while driving, but no one was associated with a car accident. The TOVA study (29) showed that the risk of ICD shock for VT/VF was higher in the 30 minutes period after driving (RR 4.46, 95\% CI 2.92 - 6.82) than during driving (RR 1.05, $95 \%$ CI 0.48 - 2.3). The authors concluded that the risk of ICD shock for VT/VF was not elevated during driving and the absolute risk was low. Finally, in 2013 Mylotte et al. (35) reported a 1.5\% annual risk of shock while driving among 275 patients implanted for primary and secondary prevention. Eight patients (3.3\%) received a shock during driving and 5/8 shocks resulted in a road traffic accident.

No trial specifically addressed the issue of ICD therapies during driving in patients implanted for primary prevention, but data extrapolated from the major primary prevention ICD trials suggest that the frequency of ICD shocks and the rate of syncopal events are low. In fact, coupling the ICD discharge rate derived from the SCD-HeFT (9), DEFINITE (8) and MADIT-II (7) trials ( 7,5\% of patients per year) with the average miles per day driven by ICD drivers ( 8 to 20 miles per day, which is $\sim 2 \%$ of the day) (26), the likelihood of an event resulting in SCI while driving is $<1 \%$ (36). Therefore it can be hypothesized that the rate of ICD shocks while driving is lower than in secondary prevention patients.

Modern ICDs are programmed to deliver bursts of antitachycardia pacing (ATP), which are effective in terminating fast VT and are associated with a low risk of syncope $(37,38)$. Kim et al. (39)reported that in a predominantly primary prevention population, the likelihood of receiving a shock at 6 months when the first ventricular arrhythmia was terminated by a shock was 30\%. By contrast, when the first ventricular arrhythmia was terminated by ATP the risk of shock was 9.9\%, 3 times lower. Consequently, ATP can further reduce the number of SCI and accidents during driving and, therefore, the duration of the driving restrictions might be less restrictive when applied to drivers receiving ATP (39).

Taken together, these data suggest that the risk of harm of ICD patients during driving is not greater than that in the general driving population (16).

\section{PROFESSIONAL DRIVERS}


The risk of harm to patients and bystanders is considerably high if SCI occurs while a professional driver is driving. Using the "Risk of Harm" formula (32), given the huge impact on the equation brought by the type of vehicle driven and the substantial amount of time spent behind the wheel, a yearly risk of SCI below 1\% should be considered as the maximum accepted value to grant a professional driving licence. However, since both primary (4-11) and secondary (40-44) prevention trials as well as studies on inherited cardiomyopathies (45, $46)$ and channelopathies $(47,48)$ showed an incidence of appropriate ICD shocks well above that cut-off value, all the national regulations and guidelines analyzed in this paper agree on the permanent prohibition of professional driving after ICD implantation for primary and secondary preventions.

In most of the countries, after PM insertion, professional drivers have a longer driving ban than private drivers, but they can return to their occupation.

Driving restrictions in ICD/PM patients according with different national regulations for both professional and private drivers are reported in table 1 and table 2 .

\section{PRIVATE DRIVERS}

\subsection{Driving restrictions in ICD patients implanted for secondary prevention}

Patients who have had an ICD implanted for secondary prevention have already experienced a life-threatening arrhythmic event.

To determine the risk of harm to patients and bystanders, and consequently the proper driving restriction period after an ICD implant, it is necessary to estimate the risk of arrhythmia recurrence and the likelihood that the arrhythmia will result in sudden incapacitation while driving. According with previous studies, the 5 years actuarial incidence of appropriate ICD shocks ranges between 55-70\% (40-43, 49). The risk of syncope associated with ICD shocks in secondary prevention patients have been evaluated by several studies and ranges from $2 \%$ to $16 \%$ with an average of $11.2 \%$ (50). Predictors of symptoms associated with ICD therapies were: presentation with cardiac arrest (40), induction of a fast VT (cycle length < $300 \mathrm{~ms}$ ) during electrophysiologic study $(40,43)$, low baseline left ventricular ejection fraction (43), chronic atrial fibrillation (43) and syncopal VT (51) prior to ICD implantation. These clinical features may help identifying high-risk patients. Indeed, in the UK Driver and Vehicle Licensing Agency (DVLA) guidelines, the temporary driving ban for patient implanted because of VT/VF with incapacity is up to six months, while it decreases to 1 month in patients implanted for sustained VT without incapacity based on 3 findings: 1) left ventricular ejection fraction $>35 \%$; 2) no fast VT is induced at electrophysiologic study; 3 ) 
any induced VT could be pace-terminated by the ICD twice, without acceleration, during the post implantation study.

Another aspect considered when deciding the duration of the driving ban comes from a study by Larsen et al. (44), showing that the hazard rate of syncope, sudden death, ICD discharge, recurrent VF or hemodynamically unstable VT was highest in the first month after hospital discharge, moderate between months 2 and 7, substantially declining thereafter. Based on this data, a driving restriction of 6 months after an ICD implant was recommended by many national societies and countries, including American Heart Association, Canada, Japan, Australia, UK DVLA and Austria.

Newer evidences came from the TOVA study (29) in 2007. In this prospective casecrossover study, Albert et al. showed that the risk of ICD shock for VT/VF within 1 hour of driving was not elevated ( 1 episode per 25,116 person-hours spent driving), while the risk was higher in the 30 min period after driving (RR 4.46, 95\% CI $2.92-6.82$ ) than during the driving episode itself (RR 1.05, 95\% CI 0.48 - 2.3). On this basis, the European Heart Rhythm Association (EHRA) 2009 guidelines (52) proposed a shorter restriction time of 3 months after ICD implant for secondary prevention for private driving, and many European countries (such as Denmark, France, Germany, Norway and Sweden) apply these standards (in the Netherlands the restriction is 2 months). Interesting data favoring an even shorter driving restriction period come from Thjissen et al. (53). In a cohort of 2,786 ICD patients (36\% implanted for secondary prevention) the annual RH was below the cut-off value of $0.005 \%$, suggesting that no specific restrictions to drive directly following ICD implant are warranted.

\subsection{Driving restrictions in ICD patients implanted for primary prevention}

ICDs as primary prevention are offered to patients at high risk of malignant ventricular arrhythmias that may lead to sudden cardiac death.

Patients with ICDs for primary prevention are considered at lower risk for sudden incapacitation than secondary prevention patients. The average annualized mortality rate reported in primary prevention trials in the ICD arm is nearly 7\% of patients per year (range $1.6 \%-12 \%$ of patients per year) (4-11). The average ICD discharge rate in recent trials was 7.5\% per year (7-9) and the mean incidence rate of syncope associated with ICD shock was $1.6 \%,(50)$ much lower than that in secondary prevention patients (11.2\%). Finally, Epstein et al. (36) showed that the likelihood of an ICD shock during driving is $\sim 0.15 \%$ of patient per year and concluded that no private car driving restrictions need to be applied to patients who are asymptomatic from an arrhythmia standpoint. 
According with these evidences, many countries recommend 1-4 weeks post-implant driving restriction (table 1 and table 2). These restrictions are not mainly due to the risk of ICD discharge; they are imposed to allow the patient to recover from surgery, the wound to heal and to cover the time period during which perforations, lead dislodgement and other complications are more likely to occur.

\section{Driving restrictions after ICD therapies}

Besides a distinction in driving restrictions between patients implanted for primary or secondary prevention, a driving ban is also applied after ICD therapies. In fact, ICD therapies (including both shocks and ATPs) represent a possible cause of SCI and car accidents. The occurrence of symptoms during the first appropriate ICD shock is considered predictive of subsequent impairment of consciousness by some authors $(40,43)$, an opinion which is not shared by others (54). Indeed, recent trials have reported a lower incidence of shock delivery and of clinical events by an improved programming aiming to avoid unnecessary therapy delivery(55-58). Though this aspect is pivotal to estimate the true occurrence of clinically relevant arrhythmias, it is not considered in the appraisal of the RH and of individual patients.

Thijssen et al. (53) suggested that a 4 or 2 months driving restriction should be applied to primary and secondary ICD patients, respectively, after the occurrence of an appropriate shock. Of note, a historical syncope rate of $31 \%$ associated with ICD shocks was used in this study. A shorter duration of driving restriction (1 month) after an ICD shock is suggested by a recent study (59), which analyzed the RH in 14,230 ICD recipients in which the estimated prevalence of loss of consciousness associated with ICD shocks was $14 \%$.

Based on these data, most countries consider most prudent to apply the same driving restrictions to primary and secondary ICD patients whether the first appropriate shock was symptomatic or not (table 1 and table 2).

Regarding inappropriate ICD shocks, the prevalence reported in major trials (60-63) ranges between $11 \%$ and $32 \%$, although this is largely outdated in newer studies applying upto-date programming and arrhythmia discriminators, showing a two-years inappropriate shock rate of $3 \%(64,65)$. Inappropriate ICD therapies may have a proarrhythmic effect $(66$, 67), but the associated incidence of syncope is little unknown yet. The only study that investigated the magnitude of sudden cardiac incapacitation risk after inappropriate ICD therapies was conducted by Watanabe et al. (68). The authors reported that inappropriate ICD therapies were responsible for syncope in only $0.7 \%$ of patients. They also calculated an annual RH to others after the first therapy, which was 0.11 in 100,000 and 0.12 in 100,000 in primary and 
secondary prevention patients respectively; a RH value which was far below the acceptable risk threshold described previously (32). The article by Watanabe et al. (68) contributed to the deregulation of driving restrictions after inappropriate ICD therapies not associated with syncope. However, significant regulatory differences between countries still remain, reflecting the lack of robust data (table 1 and table 2). For example, in Germany, France, Netherlands, Norway, Spain, Denmark and Sweden, no specific driving restriction period is set after an inappropriate ICD therapy, as long as the underlying cause has been removed. In Japan, private drivers do not have to cease from driving after an asymptomatic inappropriate ICD therapy, but they should stop for 3 months if they lost consciousness at that time. In UK, patients have to abstain from driving for 1 month after the cause of the inappropriate therapy has been corrected. In US, the driving restriction is up to 6 months.

\section{Driving restrictions in patients refusing ICD implantation}

This issue is not specifically addressed in the literature and by most of the national regulations. Since the study by Larsen et al. (44) on ICD patients implanted for secondary prevention showed that the hazard rate of syncope, sudden death, ICD discharge, recurrent VF or hemodynamically unstable VT declines starting from the first month post implant, reaching low levels at 8 months, the EU guidelines(52) suggest a seven months driving restriction in private drivers with a secondary prevention indication, refusing ICD. No driving restriction is set for private drivers refusing ICD with indication for primary prevention. Commercial drivers are not allowed to drive instead (table 1 and table 2).

\section{Driving restriction after PM insertion, generator changes and leads revisions}

Driving with a PM is substantially safe. The incidence of syncope in paced patients is low (69) and PM dysfunction is not a major cause of syncope (70). The driving ban following PM implantation, generator changes or leads revisions is imposed to let the patients recover from surgery, the wound to heal and to unmask peri-procedural complications, such as lead dislodgements, perforations and pocket problems. Since syncope at presentation could be a predictor of recurrence post-implant (69), in some countries (such as Denmark, Germany and Norway) a longer driving restriction period is suggested for patients with a history of syncope compared with asymptomatic patients (table 1 and table 2).

\section{Conclusions}


The evaluation of fitness to drive in patients with ICD/PM is considerably different worldwide and there is a large variability in national regulations and guidelines. This heterogeneity reflects the ethical and legal complexity of balancing the individual right to drive and the perception of safety from the society standpoint. While professional drivers are not allowed to drive after ICD implant, private drivers have restrictions ranging from 1 week to 12 months.

Current regulations are mainly based on historical data, which do not consider improvements in vehicles and driving environment that made driving safer (for instance, automatic emergency braking and lane keep). Recent developments in ICD technologies, programming and algorithms, and the impact of ATP on arrhythmias termination are not considered as well. A 2002 US patent (US 6,480,744 B2) by Dr. Božidar Ferek-Petrić enabling communication between the ICD and the car computer, such as the onset of an arrhythmia potentially causing cardiac incapacitation would automatically trigger braking and stopping the vehicle, was never adopted by any car manufacturer, owing to the complexity of the regulatory in this field. This highlights the need of patients-centered rather than of regulatory-compliant policies. Newer studies are warranted to address these issues, making the publication of updated and more homogeneous regulatory documents possible.

Finally, the issue of patients refusing the device or those in whom the device is not recommended based on current guidelines (but have a non-negligible sudden-death occurrence) should be more extensively addressed, since the risk of harm while driving is mainly a consequence of the underlying heart disease and not of the presence of a device itself(71, 72).

\section{Expert opinion}

Driving restrictions in patients with implantable electronic devices are an extremely intriguing and current issue. On one hand, cardiac implantable electronic devices (CIEDs) therapies while driving may result in sudden cardiac incapacitation and thus lead to serious road traffic accident. On the other hand, the right to drive is of paramount importance and driving bans affect patients both mentally and financially (17-21). Moreover, the duration of these bans are considerably different worldwide, within countries themselves and may vary even according with the physicians' discretional evaluation. This wide heterogeneity sometimes leads to confusion and complaints by the patients and to poor adherence to driving bans $(15,22,23,30,73)$. 
A reason that may explain this variability in accessing the fitness to drive in CIED patients may be found in the ethical and legal complexity of balancing the individual right to drive and the good for the society. Another reason is the lack of randomized controlled trials that specifically address this issue. Therefore, current regulations are mainly based on historical data that do not take into account improvements in CIED technologies (with a special mention to antitachycardia pacing $(37,38)$, which proved effective in terminating fast VT and is associated with a low risk of syncope) and driving environment, which in turn made driving with a CIED safer than previously thought. In particular, no trial specifically addressed the issue of ICD therapies during driving in patients implanted for primary prevention and data are extrapolated from the major primary prevention ICD trials which were made between years 2002 and 2005 and suggested that the frequency of ICD shocks $(\sim 7,5 \%$ of patients per year) and the rate of syncopal events are substantially low (7-9). A larger amount of data is available for ICD implanted for secondary prevention and evidences move towards a reassuring safety profile of ICD patients at the wheel. In 1994 Larsen et al. (44) showed that the hazard rate of syncope, sudden death, ICD discharge, recurrent VF or hemodynamically unstable VT was highest in the first month after hospital discharge and significantly lower after month 7. This study laid the basis for a driving ban of 6 months (after an ICD implant for secondary prevention), which was applied by many countries. On the contrary, such a pattern of therapy delivery was never observed in the more recent MADIT-II trial that addressed a more contemporary population. In 2007 Albert et al. (29) showed that the risk of ICD shock for VT/VF within 1 hour of driving was not elevated (1 episode per 25,116 person-hours spent driving), while the risk was higher in the 30 min period after driving (RR 4.46, 95\% CI 2.92 - 6.82) than during the driving episode itself (RR 1.05, 95\% CI 0.48 - 2.3). On this basis, many countries set a shorter driving ban of 3 months. Finally, in 2011 Thijssen et al. (53) found that in a cohort of 2,786 ICD patients (36\% implanted for secondary prevention) the annual risk of harm was below the cut-off value of $0.005 \%$, suggesting that no specific restrictions to drive directly following ICD implant are warranted.

However, newer and more specific studies are needed to update regulatory documents, to set better driving restrictions and reach homogeneity worldwide, bearing in mind that the risk of sudden cardiac incapacitation while driving is mainly a consequence of the underlying heart disease and not the presence of a CIED itself which, on the contrary, represents the therapy.

\section{Funding}


This paper was not funded.

\section{Declaration of interest}

G Boriani has received speaker's fees from Biotronik, Boston Scientific, Boehringer Ingelheim, and Medtronic. The authors have no other relevant affiliations or financial involvement with any organization or entity with a financial interest in or financial conflict with the subject matter or materials discussed in the manuscript apart from those disclosed.

\section{Reviewer disclosures}

Peer reviewers on this manuscript have no relevant financial or other relationships to disclose.

\section{References}

1. Investigators AvIDA. A comparison of antiarrhythmic-drug therapy with implantable defibrillators in patients resuscitated from near-fatal ventricular arrhythmias. N Engl J Med. 1997;337(22):1576-83. doi: 10.1056/NEJM199711273372202. PubMed PMID: 9411221.

2. Connolly SJ, Gent M, Roberts RS, Dorian P, Roy D, Sheldon RS, et al. Canadian implantable defibrillator study (CIDS) : a randomized trial of the implantable cardioverter defibrillator against amiodarone. Circulation. 2000;101(11):1297-302. doi: 10.1161/01.cir.101.11.1297. PubMed PMID: 10725290.

3. Kuck KH, Cappato R, Siebels J, Rüppel R. Randomized comparison of antiarrhythmic drug therapy with implantable defibrillators in patients resuscitated from cardiac arrest : the Cardiac Arrest Study Hamburg (CASH). Circulation. 2000;102(7):748-54. doi: 10.1161/01.cir.102.7.748. PubMed PMID: 10942742.

4. Moss AJ, Hall WJ, Cannom DS, Daubert JP, Higgins SL, Klein H, et al. Improved survival with an implanted defibrillator in patients with coronary disease at high risk for ventricular arrhythmia. Multicenter Automatic Defibrillator Implantation Trial Investigators. N Engl J Med. 1996;335(26):1933-40. doi: 10.1056/NEJM199612263352601. PubMed PMID: 8960472.

5. Bigger JT. Prophylactic use of implanted cardiac defibrillators in patients at high risk for ventricular arrhythmias after coronary-artery bypass graft surgery. Coronary Artery Bypass Graft (CABG) Patch Trial Investigators. N Engl J Med. 1997;337(22):1569-75. doi: 10.1056/NEJM199711273372201. PubMed PMID: 9371853.

6. Buxton AE, Lee KL, Fisher JD, Josephson ME, Prystowsky EN, Hafley G. A randomized study of the prevention of sudden death in patients with coronary artery disease. Multicenter Unsustained Tachycardia Trial Investigators. N Engl J Med. 1999;341(25):1882-90. doi: 10.1056/NEJM199912163412503. PubMed PMID: 10601507.

7. Moss AJ, Zareba W, Hall WJ, Klein H, Wilber DJ, Cannom DS, et al. Prophylactic implantation of a defibrillator in patients with myocardial infarction and reduced ejection fraction. N Engl J Med. 2002;346(12):877-83. Epub 2002/03/19. doi: 10.1056/NEJMoa013474. PubMed PMID: 11907286.

8. Kadish A, Dyer A, Daubert JP, Quigg R, Estes NA, Anderson KP, et al. Prophylactic defibrillator implantation in patients with nonischemic dilated cardiomyopathy. N Engl J Med. 2004;350(21):2151-8. doi: 10.1056/NEJMoa033088. PubMed PMID: 15152060.

9. Bardy GH, Lee KL, Mark DB, Poole JE, Packer DL, Boineau R, et al. Amiodarone or an implantable cardioverter-defibrillator for congestive heart failure. $N$ Engl J Med. 2005;352(3):225-37. doi: 10.1056/NEJMoa043399. PubMed PMID: 15659722. 
10. Bristow MR, Saxon LA, Boehmer J, Krueger S, Kass DA, De Marco T, et al. Cardiacresynchronization therapy with or without an implantable defibrillator in advanced chronic heart failure. N Engl J Med. 2004;350(21):2140-50. doi: 10.1056/NEJMoa032423. PubMed PMID: 15152059.

11. Hohnloser SH, Kuck KH, Dorian P, Roberts RS, Hampton JR, Hatala R, et al. Prophylactic use of an implantable cardioverter-defibrillator after acute myocardial infarction. N Engl J Med. 2004;351(24):2481-8. doi: 10.1056/NEJMoa041489. PubMed PMID: 15590950.

12. Baker SP, Spitz WU. An evaluation of the hazard created by natural death at the wheel. N Engl J Med. 1970;283(8):405-9. doi: 10.1056/NEJM197008202830806. PubMed PMID: 5429807.

13. Binns H, Camm J. Driving and arrhythmias. BMJ. 2002;324(7343):927-8. doi: 10.1136/bmj.324.7343.927. PubMed PMID: 11964323; PubMed Central PMCID: PMCPMC1122888.

14. Grubb BP. Driving and implantable cardioverter-defibrillators a clearer view. J Am Coll Cardiol. 2007;50(23):2241-2. Epub 2007/11/19. doi: 10.1016/j.jacc.2007.08.037. PubMed PMID: 18061072.

15. Finch NJ, Leman RB, Kratz JM, Gillette PC. Driving safety among patients with automatic implantable cardioverter defibrillators. JAMA. 1993;270(13):1587-8. PubMed PMID: 8371470.

16. Akiyama T, Powell JL, Mitchell LB, Ehlert FA, Baessler C, Investigators AvID. Resumption of driving after life-threatening ventricular tachyarrhythmia. N Engl J Med. 2001;345(6):391-7. doi: 10.1056/NEJM200108093450601. PubMed PMID: 11496849.

**This study quantifies the risks associated with allowing patients with life-threatening ventricular tachyarrhythmias to drive.

17. Eckert M, Jones T. How does an implantable cardioverter defibrillator (ICD) affect the lives of patients and their families? Int J Nurs Pract. 2002;8(3):152-7. PubMed PMID: 12000634.

18. Timmermans I, Jongejan N, Meine M, Doevendans $\mathrm{P}$, Tuinenburg A, Versteeg $\mathrm{H}$. Decreased Quality of Life Due to Driving Restrictions After Cardioverter Defibrillator Implantation. J Cardiovasc Nurs. 2018;33(5):474-80. doi: 10.1097/JCN.0000000000000474. PubMed PMID: 29601373.

19. Johansson I, Strömberg A. Experiences of driving and driving restrictions in recipients with an implantable cardioverter defibrillator--the patient perspective. J Cardiovasc Nurs. 2010;25(6):E1-E10. doi: 10.1097/JCN.0b013e3181e0f881. PubMed PMID: 20938245.

20. Bostwick JM, Sola CL. An updated review of implantable cardioverter/defibrillators, induced anxiety, and quality of life. Psychiatr Clin North Am. 2007;30(4):677-88. doi: 10.1016/j.psc.2007.07.002. PubMed PMID: 17938040.

21. Shea JB. Quality of life issues in patients with implantable cardioverter defibrillators: driving, occupation, and recreation. AACN Clin Issues. 2004;15(3):478-89. doi: 10.1097/00044067-200407000-00013. PubMed PMID: 15475819.

22. Jung W, Lüderitz B. Quality of life and driving in recipients of the implantable cardioverter-defibrillator. Am J Cardiol. 1996;78(5A):51-6. doi: 10.1016/s00029149(96)00502-4. PubMed PMID: 8820836.

23. Craney JM, Powers MT. Factors related to driving in persons with an implantable cardioverter defibrillator. Prog Cardiovasc Nurs. 1995;10(3):12-7. PubMed PMID: 7479657.

24. Curtis AB, Conti JB, Tucker KJ, Kubilis PS, Reilly RE, Woodard DA. Motor vehicle accidents in patients with an implantable cardioverter-defibrillator. J Am Coll Cardiol. 1995;26(1):180-4. doi: 10.1016/0735-1097(95)00133-k. PubMed PMID: 7797749. 
25. Kelly R, Warke T, Steele I. Medical restrictions to driving: the awareness of patients and doctors. Postgrad Med J. 1999;75(887):537-9. doi: 10.1136/pgmj.75.887.537. PubMed PMID: 10616686; PubMed Central PMCID: PMCPMC1741350.

26. Conti JB, Woodard DA, Tucker KJ, Bryant B, King LC, Curtis AB. Modification of patient driving behavior after implantation of a cardioverter defibrillator. Pacing Clin Electrophysiol. 1997;20(9 Pt 1):2200-4. doi: 10.1111/j.1540-8159.1997.tb04237.x. PubMed PMID: 9309744.

27. Trappe HJ, Wenzlaff P, Grellman G. Should patients with implantable cardioverterdefibrillators be allowed to drive? Observations in 291 patients from a single center over an 11-year period. J Interv Card Electrophysiol. 1998;2(2):193-201. PubMed PMID: 9870013.

28. Maas R, Ventura R, Kretzschmar C, Aydin A, Schuchert A. Syncope, driving recommendations, and clinical reality: survey of patients. BMJ. 2003;326(7379):21. doi: 10.1136/bmj.326.7379.21. PubMed PMID: 12511456; PubMed Central PMCID: PMCPMC139499.

29. Albert CM, Rosenthal L, Calkins H, Steinberg JS, Ruskin JN, Wang P, et al. Driving and implantable cardioverter-defibrillator shocks for ventricular arrhythmias: results from the TOVA study. J Am Coll Cardiol. 2007;50(23):2233-40. Epub 2007/11/19. doi: 10.1016/j.jacc.2007.06.059. PubMed PMID: 18061071.

** Large study that adresses the the risk of ICD shock during driving as compared with that during other activities. Provides reassurance that driving with an ICD should not imply an important rate of personal or public injury.

30. Hickey K, Curtis AB, Lancaster S, Larsen G, Warwick D, McAnulty J, et al. Baseline factors predicting early resumption of driving after life-threatening arrhythmias in the Antiarrhythmics Versus Implantable Defibrillators (AVID) Trial. Am Heart J. 2001;142(1):99104. doi: 10.1067/mhj.2001.115787. PubMed PMID: 11431664.

31. Baessler C, Murphy S, Gebhardt L, Tso T, Ellenbogen K, Leman R, et al. Time to resumption of driving after implantation of an automatic defibrillator (from the Dual chamber and VVI Implantable Defibrillator [DAVID] trial). Am J Cardiol. 2005;95(5):665-6. doi: 10.1016/j.amjcard.2004.10.048. PubMed PMID: 15721116.

32. Simpson C, Dorian P, Gupta A, Hamilton R, Hart S, Hoffmaster B, et al. Assessment of the cardiac patient for fitness to drive: drive subgroup executive summary. Can J Cardiol. 2004;20(13):1314-20. PubMed PMID: 15565193.

33. Assessment of the cardiac patient for fitness to drive. Can J Cardiol. 1992;8(4):406-19. PubMed PMID: 1617524.

** Cornerstone of risk stratification for CIED patients at the wheel.

34. Ontario Ministry of Transportation. Ontario Road Safety Annual Report. Toronto; 1987.

35. Mylotte D, Sheahan RG, Nolan PG, Neylon MA, McArdle B, Constant O, et al. The implantable defibrillator and return to operation of vehicles study. Europace. 2013;15(2):212-8. Epub 2012/09/11. doi: 10.1093/europace/eus254. PubMed PMID: 22968849.

36. Epstein AE, Baessler CA, Curtis AB, Estes NA, Gersh BJ, Grubb B, et al. Addendum to "Personal and public safety issues related to arrhythmias that may affect consciousness: implications for regulation and physician recommendations: a medical/scientific statement from the American Heart Association and the North American Society of Pacing and Electrophysiology": public safety issues in patients with implantable defibrillators: a scientific statement from the American Heart Association and the Heart Rhythm Society. Circulation. 2007;115(9):1170-6. Epub 2007/02/07. doi: 10.1161/CIRCULATIONAHA.106.180203. PubMed PMID: 17287391.

*American referral guideline.

37. Wathen MS, DeGroot PJ, Sweeney MO, Stark AJ, Otterness MF, Adkisson WO, et al. Prospective randomized multicenter trial of empirical antitachycardia pacing versus shocks 
for spontaneous rapid ventricular tachycardia in patients with implantable cardioverterdefibrillators: Pacing Fast Ventricular Tachycardia Reduces Shock Therapies (PainFREE Rx II) trial results. Circulation. 2004;110(17):2591-6. Epub 2004/10/18. doi: 10.1161/01.CIR.0000145610.64014.E4. PubMed PMID: 15492306.

38. Gulizia MM, Piraino L, Scherillo M, Puntrello C, Vasco C, Scianaro MC, et al. A randomized study to compare ramp versus burst antitachycardia pacing therapies to treat fast ventricular tachyarrhythmias in patients with implantable cardioverter defibrillators: the PITAGORA ICD trial. Circ Arrhythm Electrophysiol. 2009;2(2):146-53. Epub 2009/02/13. doi: 10.1161/CIRCEP.108.804211. PubMed PMID: 19808459.

39. Kim MH, Zhang Y, Sakaguchi S, Goldberger JJ, Investigators OS. Time course of appropriate implantable cardioverter-defibrillator therapy and implications for guidelinebased driving restrictions. Heart Rhythm. 2015;12(8):1728-36. Epub 2015/04/28. doi: 10.1016/j.hrthm.2015.04.037. PubMed PMID: 25933503.

40. Freedberg NA, Hill JN, Fogel RI, Prystowsky EN, Group C. Recurrence of symptomatic ventricular arrhythmias in patients with implantable cardioverter defibrillator after the first device therapy: implications for antiarrhythmic therapy and driving restrictions. CARE Group. J Am Coll Cardiol. 2001;37(7):1910-5. doi: 10.1016/s0735-1097(01)01226-8. PubMed PMID: 11401131.

41. Levine JH, Mellits ED, Baumgardner RA, Veltri EP, Mower M, Grunwald L, et al. Predictors of first discharge and subsequent survival in patients with automatic implantable cardioverter-defibrillators. Circulation. 1991;84(2):558-66. doi: 10.1161/01.cir.84.2.558. PubMed PMID: 1860200.

42. Grimm W, Flores BF, Marchlinski FE. Symptoms and electrocardiographically documented rhythm preceding spontaneous shocks in patients with implantable cardioverter-defibrillator. Am J Cardiol. 1993;71(16):1415-8. doi: 10.1016/00029149(93)90602-9. PubMed PMID: 8517386.

43. Bänsch D, Brunn J, Castrucci M, Weber M, Gietzen F, Borggrefe M, et al. Syncope in patients with an implantable cardioverter-defibrillator: incidence, prediction and implications for driving restrictions. J Am Coll Cardiol. 1998;31(3):608-15. doi: 10.1016/s07351097(97)00543-3. PubMed PMID: 9502643.

44. Larsen GC, Stupey MR, Walance CG, Griffith KK, Cutler JE, Kron J, et al. Recurrent cardiac events in survivors of ventricular fibrillation or tachycardia. Implications for driving restrictions. JAMA. 1994;271(17):1335-9. PubMed PMID: 8158818.

**Interesting study that helped setting the cut-off for driving restriction periods after ICD implant.

45. Mazzanti A, Ng K, Faragli A, Maragna R, Chiodaroli E, Orphanou N, et al. Arrhythmogenic Right Ventricular Cardiomyopathy: Clinical Course and Predictors of Arrhythmic Risk. J Am Coll Cardiol. 2016;68(23):2540-50. doi: 10.1016/j.jacc.2016.09.951. PubMed PMID: 27931611.

46. O'Mahony C, Lambiase PD, Quarta G, Cardona M, Calcagnino M, Tsovolas K, et al. The long-term survival and the risks and benefits of implantable cardioverter defibrillators in patients with hypertrophic cardiomyopathy. Heart. 2012;98(2):116-25. Epub 2011/07/13. doi: 10.1136/hrt.2010.217182. PubMed PMID: 21757459.

47. Schwartz PJ, Spazzolini C, Priori SG, Crotti L, Vicentini A, Landolina M, et al. Who are the long-QT syndrome patients who receive an implantable cardioverter-defibrillator and what happens to them?: data from the European Long-QT Syndrome Implantable Cardioverter-Defibrillator (LQTS ICD) Registry. Circulation. 2010;122(13):1272-82. Epub 2010/09/13. doi: 10.1161/CIRCULATIONAHA.110.950147. PubMed PMID: 20837891.

48. Sacher F, Probst V, Iesaka Y, Jacon P, Laborderie J, Mizon-Gérard F, et al. Outcome after implantation of a cardioverter-defibrillator in patients with Brugada syndrome: a multicenter 
study. Circulation. 2006;114(22):2317-24. Epub 2006/11/20. doi: 10.1161/CIRCULATIONAHA.106.628537. PubMed PMID: 17116772.

49. Curtis JJ, Walls JT, Boley TM, Stephenson HE, Schmaltz RA, Nawarawong W, et al. Time to first pulse after automatic implantable cardioverter defibrillator implantation. Ann Thorac Surg. 1992;53(6):984-7. doi: 10.1016/0003-4975(92)90371-a. PubMed PMID: 1596160.

50. Watanabe E, Abe $\mathrm{H}$, Watanabe S. Driving restrictions in patients with implantable cardioverter defibrillators and pacemakers. J Arrhythm. 2017;33(6):594-601. Epub 2017/03/28. doi: 10.1016/j.joa.2017.02.003. PubMed PMID: 29255507; PubMed Central PMCID: PMCPMC5728711.

*Remarkable review that shed lights on Japanese driving restrictions after CIED implant.

51. Abello M, Merino JL, Peinado R, Gnoatto M, Arias MA, Gonzalez-Vasserot M, et al. Syncope following cardioverter defibrillator implantation in patients with spontaneous syncopal monomorphic ventricular tachycardia. Eur Heart J. 2006;27(1):89-95. Epub 2005/09/23. doi: 10.1093/eurheartj/ehi500. PubMed PMID: 16183691.

52. Vijgen J, Botto G, Camm J, Hoijer CJ, Jung W, Le Heuzey JY, et al. Consensus statement of the European Heart Rhythm Association: updated recommendations for driving by patients with implantable cardioverter defibrillators. Europace. 2009;11(8):1097-107. Epub 2009/06/13. doi: 10.1093/europace/eup112. PubMed PMID: 19525498.

*European referral guideline that includes a comprehensive literature review.

53. Thijssen J, Borleffs CJ, van Rees JB, de Bie MK, van der Velde ET, van Erven L, et al. Driving restrictions after implantable cardioverter defibrillator implantation: an evidencebased approach. Eur Heart J. 2011;32(21):2678-87. Epub 2011/06/05. doi: 10.1093/eurheartj/ehr161. PubMed PMID: 21646229; PubMed Central PMCID: PMCPMC3205477.

54. Kou WH, Calkins H, Lewis RR, Bolling SF, Kirsch MM, Langberg JJ, et al. Incidence of loss of consciousness during automatic implantable cardioverter-defibrillator shocks. Ann Intern Med. 1991;115(12):942-5. doi: 10.7326/0003-4819-115-12-942. PubMed PMID: 1952491.

55. Silvia G. Priori CN, Mirella Memmi, Barbara Colombi, Fabrizio Drago, Maurizio, Gasparini LD, Fernando Coltorti, Raffaella Bloise, Roberto Keegan, Fernando E.S. Cruz Filho, Gabriele Vignati, Abraham Benatar and Angelica DeLogu. Clinical and Molecular Characterization of Patients With Catecholaminergic Polymorphic Ventricular Tachycardia. doi: 10.1161/01.CIR.0000020013.73106.D8.

56. Moss AJ, Schuger C, Beck CA, Brown MW, Cannom DS, Daubert JP, et al. Reduction in inappropriate therapy and mortality through ICD programming. $N$ Engl J Med. 2012;367(24):2275-83. Epub 2012/11/06. doi: 10.1056/NEJMoa1211107. PubMed PMID: 23131066.

57. Gasparini M, Proclemer A, Klersy C, Kloppe A, Lunati M, Ferrer JB, et al. Effect of longdetection interval vs standard-detection interval for implantable cardioverter-defibrillators on antitachycardia pacing and shock delivery: the ADVANCE III randomized clinical trial. JAMA. 2013;309(18):1903-11. doi: 10.1001/jama.2013.4598. PubMed PMID: 23652522.

58. Gasparini M, Lunati MG, Proclemer A, Arenal A, Kloppe A, Martínez Ferrer JB, et al. Long Detection Programming in Single-Chamber Defibrillators Reduces Unnecessary Therapies and Mortality: The ADVANCE III Trial. JACC Clin Electrophysiol. 2017;3(11):127582. Epub 2017/05/31. doi: 10.1016/j.jacep.2017.05.001. PubMed PMID: 29759624.

59. Merchant FM, Hoskins MH, Benser ME, Roberts G, Bastek AN, Knezevic A, et al. Time Course of Subsequent Shocks After Initial Implantable Cardioverter-Defibrillator Discharge and Implications for Driving Restrictions. JAMA Cardiol. 2016;1(2):181-8. doi: 10.1001/jamacardio.2015.0386. PubMed PMID: 27437889.

60. Daubert JP, Zareba W, Cannom DS, McNitt S, Rosero SZ, Wang P, et al. Inappropriate implantable cardioverter-defibrillator shocks in MADIT II: frequency, mechanisms, predictors, 
and survival impact. J Am Coll Cardiol. 2008;51(14):1357-65. doi: 10.1016/j.jacc.2007.09.073. PubMed PMID: 18387436.

61. Klein RC, Raitt MH, Wilkoff BL, Beckman KJ, Coromilas J, Wyse DG, et al. Analysis of implantable cardioverter defibrillator therapy in the Antiarrhythmics Versus Implantable Defibrillators (AVID) Trial. J Cardiovasc Electrophysiol. 2003;14(9):940-8. doi: 10.1046/j.1540-8167.2003.01554.x. PubMed PMID: 12950538.

62. Alter P, Waldhans S, Plachta E, Moosdorf R, Grimm W. Complications of implantable cardioverter defibrillator therapy in 440 consecutive patients. Pacing Clin Electrophysiol. 2005;28(9):926-32. doi: 10.1111/j.1540-8159.2005.00195.x. PubMed PMID: 16176531.

63. Sweeney MO, Wathen MS, Volosin K, Abdalla I, DeGroot PJ, Otterness MF, et al. Appropriate and inappropriate ventricular therapies, quality of life, and mortality among primary and secondary prevention implantable cardioverter defibrillator patients: results from the Pacing Fast VT REduces Shock ThErapies (PainFREE Rx II) trial. Circulation. 2005;111(22):2898-905. Epub 2005/05/31. doi: 10.1161/CIRCULATIONAHA.104.526673. PubMed PMID: 15927965.

64. Auricchio A, Schloss EJ, Kurita T, Meijer A, Gerritse B, Zweibel S, et al. Low inappropriate shock rates in patients with single- and dual/triple-chamber implantable cardioverter-defibrillators using a novel suite of detection algorithms: PainFree SST trial primary results. Heart Rhythm. 2015;12(5):926-36. Epub 2015/01/28. doi: 10.1016/j.hrthm.2015.01.017. PubMed PMID: 25637563.

65. Cheng A, Auricchio A, Schloss EJ, Kurita T, Sterns LD, Gerritse B, et al. SVT discrimination algorithms significantly reduce the rate of inappropriate therapy in the setting of modern-day delayed high-rate detection programming. J Cardiovasc Electrophysiol. 2019;30(12):2877-84. Epub 2019/11/05. doi: 10.1111/jce.14250. PubMed PMID: 31646695.

66. Pinski SL, Fahy GJ. The proarrhythmic potential of implantable cardioverterdefibrillators. Circulation. 1995;92(6):1651-64. doi: 10.1161/01.cir.92.6.1651. PubMed PMID: 7664453.

67. Germano JJ, Reynolds M, Essebag V, Josephson ME. Frequency and causes of implantable cardioverter-defibrillator therapies: is device therapy proarrhythmic? Am J Cardiol. 2006;97(8):1255-61. Epub 2006/03/09. doi: 10.1016/j.amjcard.2005.11.048. PubMed PMID: 16616037.

68. Watanabe E, Okajima K, Shimane A, Ozawa T, Manaka T, Morishima I, et al. Inappropriate implantable cardioverter defibrillator shocks-incidence, effect, and implications for driver licensing. J Interv Card Electrophysiol. 2017;49(3):271-80. Epub 2017/07/20. doi: 10.1007/s10840-017-0272-4. PubMed PMID: 28730420; PubMed Central PMCID: PMCPMC5543197.

69. Sgarbossa EB, Pinski SL, Jaeger FJ, Trohman RG, Maloney JD. Incidence and predictors of syncope in paced patients with sick sinus syndrome. Pacing Clin Electrophysiol. 1992;15(11 Pt 2):2055-60. doi: 10.1111/j.1540-8159.1992.tb03021.x. PubMed PMID: 1279599.

70. Pavlovic SU, Kocovic D, Djordjevic M, Belkic K, Kostic D, Velimirovic D. The etiology of syncope in pacemaker patients. Pacing Clin Electrophysiol. 1991;14(12):2086-91. doi: 10.1111/j.1540-8159.1991.tb06478.x. PubMed PMID: 1723190.

71. Exner DV, Kavanagh KM, Slawnych MP, Mitchell LB, Ramadan D, Aggarwal SG, et al. Noninvasive risk assessment early after a myocardial infarction the REFINE study. J Am Coll Cardiol. 2007;50(24):2275-84. Epub 2007/11/26. doi: 10.1016/j.jacc.2007.08.042. PubMed PMID: 18068035.

72. Bauer A, Klemm M, Rizas KD, Hamm W, von Stülpnagel L, Dommasch M, et al. Prediction of mortality benefit based on periodic repolarisation dynamics in patients undergoing prophylactic implantation of a defibrillator: a prospective, controlled, multicentre 
cohort study. Lancet. 2019;394(10206):1344-51. Epub 2019/09/02. doi: 10.1016/S01406736(19)31996-8. PubMed PMID: 31488371.

73. Jongejan N, Timmermans I, Elders J, Meijer K, Meine M, Doevendans PA, et al. Driving restrictions for Dutch patients with an implantable cardioverter defibrillator : Compliance and associated factors. Neth Heart J. 2018;26(2):69-75. doi: 10.1007/s12471-017-1067-z. PubMed PMID: 29260463; PubMed Central PMCID: PMCPMC5783892.

74. The Expert Group on Driving and Cardiovascular Disease. New Standards for Driving and Cardiovascular Diseases. Brussels:?The Expert Group on Driving and Cardiovascular Disease, October 2013. Available at: https://ec.europa.eu/transport/road safety/sites/roadsafety/files/pdf/behavior/driv ing and cardiovascular disease final.pdf.

75. Leitlinien für die gesundheitliche eignung von kraftfahrzeuglenkern, 2018. Available at https://www.bmvit.gv.at/verkehr/strasse/recht/fsg/erlaesse/downloads/gesundheit leitlini en.pdf.

76. Belgisch staatsblad. Wetten, decreten, ordonnanties en verordeningen. 30.04.1998. Available

https://www.health.belgium.be/sites/default/files/uploads/fields/fpshealth theme file/ar 2 3.03.1998 concernant les chauffeurs.pdf.

77. Kørekort hos patienter med hjertelidelser. Jens Jakob Thune, Morten Steen Kvistholm Jensen, Regitze Videbæk og Sam Riahi. Revideret af DCS arbejdsgruppe for Præentiv Kardiologi og Hjerterehabilitering. Available at: https://www.nbv.cardio.dk/korekort.

78. Arrêté du 16 décembre 2017 modifiant l'arrêté du 21 décembre 2005 modifié fixant la liste des affections médicales incompatibles avec l'obtention ou le maintien du permis de conduire ou pouvant donner lieu à la délivrance de permis de conduire de durée de validité limitée 21 Dècembre 2017. Journal officiel de larépublique française. Available at: https://www.legifrance.gouv.fr/jo pdf.do?id=JORFTEXT000036239920.

79. Begutachtungsleitlinien zur Kraftfahreignung. Available at: www.bast.de/DE/Ver kehrssicherheit/Fachthemen/BLL/BLL-Hintergrund.html.

80. Klein HH, Sechtem U, Trappe HJ. Fitness to Drive in Cardiovascular Disease. Dtsch Arztebl Int. 2017;114(41):692-702. doi: 10.3238/arztebl.2017.0692. PubMed PMID: 29082864; PubMed Central PMCID: PMCPMC5672600.

81. Decreto Ministero dei Trasporti - 26/01/2018 - Modifiche ai requisiti di idoneità psicofisica.

Available

at: http://www.patente.it/ecom.dll/noAjax?idc=3711and http://www.patente.it/ecom.d ll/noAjax?idc $=1590$.

82. Staatscourant. Regeling van de Minister van Infrastructuur en Waterstaat. 2017. Available at: https://zoek.officielebekendmakingen.nl/stcrt-2017-69981.html. .

83. Forskrift om førerkort m.m.,2004 hefte 3. Available at: https://lovdata.no/dokument/LTI/forskrift/2004-01-19-298.

84. Boletin oficial del estado. 12/04/2018. Orden PRA/375/2018, de 11 de abril, por la que se modifica el anexo IV del Reglamento General de Conductores, aprobado por Real Decreto 818/2009, de 8 de mayo. Available at: https://www.boe.es/eli/es/o/2018/04/11/pra375.

85. TSFS 2010:125. Transportstyrelsens föreskrifter och allmänna råd om medicinska krav för innehav av körkort m.m. Available at: https://www.transportstyrelsen.se/TSFS/TSFS 2010 125k.pdf.

86. The Driver and Vehicle Licensing Agency. Assessing fitness to drive - a guide for medical professionals. Swansea: DVLA, August 2018. Available at: www.gov.uk/guidance/assessingfitness- to-drive-a-guide-for-medical-professionals. 
87. Margulescu AD, Anderson MH. A Review of Driving Restrictions in Patients at Risk of Syncope and Cardiac Arrhythmias Associated with Sudden Incapacity: Differing Global Approaches to Regulation and Risk. Arrhythm Electrophysiol Rev. 2019;8(2):90-8. doi: 10.15420/aer.2019.13.2. PubMed PMID: 31114682; PubMed Central PMCID: PMCPMC6528027.

88. Epstein AE, Miles WM, Benditt DG, Camm AJ, Darling EJ, Friedman PL, et al. Personal and public safety issues related to arrhythmias that may affect consciousness: implications for regulation and physician recommendations. A medical/scientific statement from the American Heart Association and the North American Society of Pacing and Electrophysiology. Circulation. 1996;94(5):1147-66. doi: 10.1161/01.cir.94.5.1147. PubMed PMID: 8790068.

89. Canadian Council of Motor Transport Administration. Determining Driver Fitness in Canada. Part 1: A Model for the Administration of Driver Fitness Programs Part 2: CCMTA Medical Standards for Drivers. Ontario: CCMTA, March 2017. Available? at: www.ccmta.ca/images/pdf-documents-english/CCMTA-Medical-Standards-2017-English.pdf 90. Austroads. Assessing Fitness to Drive for commercial and private vehicle drivers. Sydney: Austroads, August $2017 . \quad$ Available at:https://austroads.com.au/ data/assets/pdf_file/0022/104197/AP-G56-

17_Assessing_fitness_to_drive_2016_amended_Aug2017.pdf

91. EUR-Lex. Directive 2006/126/EC of the European Parliament and of the Council of 20 December 2006 on driving licences. Available at: https://eur-lex.europa.eu/legalcontent/EN/TXT/?uri=celex:32006L0126.

92. Digest of motor laws. Types of driver's licenses. Available at: http://drivinglaws.aaa.com/tag/types-of-drivers-licenses/.

93. Federal Motor Carrier Safety Administration. Commercial Driver License Manual. Available at: https://www.fmcsa.dot.gov/sites/fmcsa.dot.gov/files/docs/2005 CDL Driver Manual -July 2014 - FINAL.pdf.

94. Assessment of the cardiac patient for fitness to drive: 1996 update. Can J Cardiol. 1996;12(11):1164-70, 75-82. PubMed PMID: 9191510. 


\begin{tabular}{|c|c|c|c|c|c|c|c|c|}
\hline Country & \multicolumn{2}{|c|}{ EU } & \multicolumn{2}{|l|}{ Austria } & \multicolumn{2}{|c|}{ Belgium } & \multicolumn{2}{|c|}{ Denmark } \\
\hline Document type & \multicolumn{2}{|c|}{ Consensus document } & \multicolumn{2}{|c|}{ Consensus document } & \multicolumn{2}{|c|}{ Administrative document } & \multicolumn{2}{|c|}{ Consensus document } \\
\hline $\begin{array}{l}\text { Driving licence } \\
\text { group }\end{array}$ & Private & Commercial & Private & Commercial & Private & Commercial & Private & Commercial \\
\hline \multicolumn{9}{|l|}{$I C D$} \\
\hline $\begin{array}{l}\text { Secondary } \\
\text { prevention }\end{array}$ & 3 months & NA & 6 months * & NA & $\begin{array}{c}12 \\
\text { months }\end{array}$ & $N A$ & $\begin{array}{c}1 \text { week and } 3 \text { months } \\
\text { after last VF/VT }\end{array}$ & NA \\
\hline $\begin{array}{l}\text { Primary } \\
\text { prevention }\end{array}$ & 4 weeks & NA & $\begin{array}{l}4 \text { weeks in asymptomatic } \\
\text { patients if LVEF > 35\%; no rapid } \\
\text { VT induced during EPS (RR } \\
<250 \text { ms); induced VT can be } \\
\text { terminated twice by the ICD } \\
\text { without acceleration during } \\
\text { post-implantation examination }\end{array}$ & NA & $\begin{array}{c}12 \\
\text { months }\end{array}$ & NA & $\begin{array}{l}2 \text { weeks ( } 1 \text { week if home } \\
\text { monitoring established) }\end{array}$ & NA \\
\hline $\begin{array}{l}\text { Generator } \\
\text { change }\end{array}$ & 1 week & & 4 weeks & & $N R$ & & 1 week & \\
\hline Lead revision & 4 weeks & & 4 weeks & & & & $\begin{array}{c}2 \text { weeks } \\
\text { (1week if home } \\
\text { monitoring established) }\end{array}$ & \\
\hline $\begin{array}{l}\text { Primary } \\
\text { indication, } \\
\text { patient } \\
\text { refusing device }\end{array}$ & NR & NA & & & & & $\mathrm{NR}$ & NA \\
\hline $\begin{array}{l}\text { Secondary } \\
\text { indication, } \\
\text { patient } \\
\text { refusing device }\end{array}$ & 7 months & NA & & & & & 3 months & NA \\
\hline $\begin{array}{l}\text { Appropriate } \\
\text { therapy }\end{array}$ & 3 months & & 6 months & & & & $\begin{array}{c}3 \text { months } \\
\text { (No restrictions for ATP) }\end{array}$ & \\
\hline $\begin{array}{l}\text { Inappropriate } \\
\text { therapy }\end{array}$ & $\begin{array}{c}\text { Until measures to } \\
\text { prevent subsequent } \\
\text { inappropriate therapy } \\
\text { are taken } \\
\end{array}$ & & & & & & $\begin{array}{c}\text { Until measures to } \\
\text { prevent subsequent } \\
\text { inappropriate therapy } \\
\text { are taken }\end{array}$ & \\
\hline \multicolumn{9}{|l|}{ PACEMAKER } \\
\hline Insertion & $\begin{array}{c}\text { NR } \\
\text { Wound healing and PM } \\
\text { functioning has to be } \\
\text { confirmed }\end{array}$ & $\begin{array}{l}2 \text { weeks and wound } \\
\text { healing and PM } \\
\text { functioning has to be } \\
\text { confirmed }\end{array}$ & 1 week & 1 week & 4 weeks & 12 weeks & 1 week & $\begin{array}{c}1 \text { week } \\
\text { (2 weeks if history } \\
\text { of syncope) }\end{array}$ \\
\hline $\begin{array}{l}\text { Generator } \\
\text { change }\end{array}$ & $\begin{array}{c}\text { NR } \\
\text { Wound healing and PM } \\
\text { functioning has to be } \\
\text { confirmed }\end{array}$ & $\begin{array}{l}2 \text { weeks and wound } \\
\text { healing and PM } \\
\text { functioning has to be } \\
\text { confirmed }\end{array}$ & 1 week & 1 week & NR & 2 weeks & & \\
\hline Lead revision & & & & & 4 weeks & 12 weeks & & \\
\hline
\end{tabular}




\begin{tabular}{|c|c|c|c|c|c|c|c|c|}
\hline \multirow{3}{*}{$\begin{array}{l}\text { Country } \\
\text { Document type } \\
\text { Driving licence } \\
\text { group }\end{array}$} & \multicolumn{2}{|c|}{ France } & \multicolumn{2}{|c|}{ Germany } & \multicolumn{2}{|c|}{ Italy } & \multicolumn{2}{|c|}{ Netherlands } \\
\hline & \multicolumn{2}{|c|}{ Administrative document } & \multicolumn{2}{|c|}{ Administrative document } & \multicolumn{2}{|c|}{$\begin{array}{c}\text { Administrative } \\
\text { document }\end{array}$} & \multicolumn{2}{|c|}{ Administrative document } \\
\hline & Private & Commercial & Private & Commercial & Private & Commercial & Private & Commercial \\
\hline \multicolumn{9}{|l|}{ ICD } \\
\hline $\begin{array}{l}\text { Secondary } \\
\text { prevention }\end{array}$ & 3 months & NA & 3 months & NA & $\begin{array}{l}\text { Tailored } \\
\text { ban }\end{array}$ & NA & 2 months & NA \\
\hline $\begin{array}{l}\text { Primary } \\
\text { prevention }\end{array}$ & 2 weeks & NA & 1 - 2 weeks & NA & $\begin{array}{c}\text { Tailored } \\
\text { ban }\end{array}$ & NA & 2 weeks & NA \\
\hline $\begin{array}{l}\text { Generator } \\
\text { change }\end{array}$ & $\begin{array}{l}\text { NR: according with } \\
\text { specialized opinion }\end{array}$ & & 1 week & & $\begin{array}{c}\text { Tailored } \\
\text { ban }\end{array}$ & & & \\
\hline Lead revision & $\begin{array}{l}\text { NR: according with } \\
\text { specialized opinion }\end{array}$ & & 1 - 2 weeks & & & & & \\
\hline $\begin{array}{l}\text { Primary } \\
\text { indication, } \\
\text { patient refusing } \\
\text { device }\end{array}$ & & NA & & & & & & \\
\hline $\begin{array}{l}\text { Secondary } \\
\text { indication, } \\
\text { patient refusing } \\
\text { device }\end{array}$ & & NA & & & & & & \\
\hline $\begin{array}{l}\text { Appropriate } \\
\text { therapy }\end{array}$ & 3 months & & 3 months & 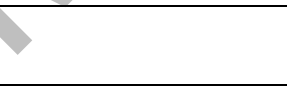 & $\begin{array}{l}\text { Tailored } \\
\text { ban }\end{array}$ & & 2 months & \\
\hline $\begin{array}{l}\text { Inappropriate } \\
\text { therapy }\end{array}$ & $\begin{array}{c}\text { Until measures to prevent } \\
\text { subsequent inappropriate } \\
\text { therapy are taken }\end{array}$ & & $\begin{array}{c}\text { Until measures to prevent } \\
\text { subsequent inappropriate } \\
\text { therapy are taken }\end{array}$ & & $\begin{array}{c}\text { Tailored } \\
\text { ban }\end{array}$ & & $\begin{array}{l}\text { Until measures to prevent } \\
\text { subsequent inappropriate } \\
\text { therapy are taken }\end{array}$ & \\
\hline \multicolumn{9}{|l|}{ PACEMAKER } \\
\hline Insertion & $\begin{array}{c}\text { NR } \\
\text { According with specialized } \\
\text { opinion }\end{array}$ & $\begin{array}{l}2 \text { weeks } \\
\text { According with } \\
\text { specialized } \\
\text { opinion }\end{array}$ & $\begin{array}{c}\text { NR } \\
\text { Wound healing and PM } \\
\text { functioning has to be } \\
\text { confirmed }\end{array}$ & $\begin{array}{c}1 \text { week } \\
\text { (4 weeks if history of } \\
\text { syncope or PM } \\
\text { dependent patient) }\end{array}$ & NR & $\begin{array}{l}\text { Tailored } \\
\text { ban }\end{array}$ & $N R$ & \\
\hline $\begin{array}{l}\text { Generator } \\
\text { change }\end{array}$ & & & $\begin{array}{c}\text { NR } \\
\text { Wound healing and PM } \\
\text { functioning has to be } \\
\text { confirmed }\end{array}$ & $\begin{array}{c}1 \text { week } \\
\text { (4 weeks if history of } \\
\text { syncope or PM } \\
\text { dependent patient) }\end{array}$ & NR & $\begin{array}{l}\text { Tailored } \\
\text { ban }\end{array}$ & 2 weeks & \\
\hline Lead revision & & & $\begin{array}{c}\text { NR } \\
\text { Wound healing and PM } \\
\text { functioning has to be } \\
\text { confirmed }\end{array}$ & 4 weeks & & & & \\
\hline
\end{tabular}




\begin{tabular}{|c|c|c|c|c|c|c|c|c|}
\hline Country & Nor & & Spain & & Sweden & & $\mathrm{U}$ & \\
\hline Document type & Administrati & document & Administrative & ument & Administrative do & nent & Administrati & ument \\
\hline Driving licence group & Private & Commercial & Private & Commercial & Private & Commercial & Private & Commercial \\
\hline$I C D$ & & & & & & & & \\
\hline Secondary prevention & 3 months & NA & 3 months & NA & 3 months & NA & 6 months** & NA \\
\hline Primary prevention & 1 week & NA & 2 weeks & NA & 2 weeks & NA & 4 weeks & NA \\
\hline Generator change & 1 week pain free & & & & $\begin{array}{c}2 \text { weeks } \\
\text { (Primary prevention) }\end{array}$ & & 1 week & \\
\hline Lead revision & 1 week & & & & & & 4 weeks & \\
\hline $\begin{array}{l}\text { Primary indication, } \\
\text { patient refusing device }\end{array}$ & & & & & & & & \\
\hline $\begin{array}{l}\text { Secondary indication, } \\
\text { patient refusing device }\end{array}$ & $\begin{array}{l}\text { Health requirements } \\
\text { apply as with specific } \\
\text { cardiac condition }\end{array}$ & NA & & & & & & \\
\hline Appropriate therapy & 3 months & & 3 months & & 3 months & & $\begin{array}{l}6 \text { months (if no } \\
\text { incapacity). } \\
\text { If incapacity: stop for } \\
\text { two years. Six months } \\
\text { if steps to control } \\
\text { arrhythmia are taken } \\
\text { (antiarrhythmics/ } \\
\text { ablation) and no } \\
\text { recurrence. } \\
\text { Includes ATP }\end{array}$ & \\
\hline Inappropriate therapy & $\begin{array}{c}\text { Until measures to } \\
\text { prevent subsequent } \\
\text { inappropriate therapy } \\
\text { are taken }\end{array}$ & & $\begin{array}{c}\text { Until measures to } \\
\text { prevent subsequent } \\
\text { inappropriate therapy } \\
\text { are taken }\end{array}$ & & $\begin{array}{l}\text { Until measures to prevent } \\
\text { subsequent inappropriate } \\
\text { therapy are taken }\end{array}$ & & $\begin{array}{c}1 \text { month after } \\
\text { underlying cause has } \\
\text { been removed }\end{array}$ & \\
\hline PACEMAKER & & & & & & & & \\
\hline Insertion & 1 week & $\begin{array}{l}1 \text { week (4 weeks if } \\
\text { history of syncope) }\end{array}$ & 2 weeks & 4 weeks & NR & 2 weeks & 1 week & 6 weeks \\
\hline Generator change & & & $2 \sqrt{2-1}$ & & NR & 2 weeks & 1 week & 6 weeks \\
\hline Lead revision & & & 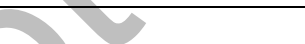 & & & & & \\
\hline
\end{tabular}

Table 1: Driving restrictions after implantation of cardiac implantable electronic devices in Europe and in 11 European countries.

* Other conditions: 1) the device has not delivered any treatment (shock and/or ATP for symptomatic tachycardia) within the last 6 months (except for formal clinical testing). 2) No ICD therapy over the past 2 years since implantation of the device has been accompanied by syncope, presyncope or abnormality (either caused by the device or the arrhythmia), except: the underlying cause has been identified and controlled. 3) A break of 1 month after each change of antiarrhythmic drug treatment should be followed. ** Driving may resume 1 month after implantation provided all of the following are met: 1) presentation was a "non-disqualifying" cardiac event (i.e. haemodynamically stable sustained ventricular tachycardia without incapacity), 2) left ventricular ejection fraction is greater than $35 \%, 3$ ) any ventricular tachycardia (VT) induced on electrophysiological study (EPS) has RR interval greater than 250 milliseconds, 4) during the post implantation EPS, any induced VT could be pace-terminated by the ICD twice, without acceleration. If any of the above not met, must not drive for 6 months following implantation; ATP = antitachycardia pacing; CA = cardiac arrest; EPS = electrophysiological study; $I C D=$ implantable cardioverter defibrillator; $L V E F=$ left ventricular ejection fraction; NA = not allowed; NR = no restriction; PM = pacemaker; SVT = sustained ventricular tachycardia; VF = ventricular fibrillation; VT = ventricular tachycardia.

References $(52,74-87)$. 


\begin{tabular}{|c|c|c|c|c|c|c|c|c|c|c|}
\hline Country & \multicolumn{2}{|c|}{ Europe } & \multicolumn{2}{|c|}{ US } & \multicolumn{2}{|c|}{ Canada } & \multicolumn{2}{|c|}{ Australia } & \multicolumn{2}{|c|}{ Japan } \\
\hline Document type & \multicolumn{2}{|c|}{ Consensus document } & \multicolumn{2}{|c|}{ Consensus document } & \multicolumn{2}{|c|}{ Administrative document } & \multicolumn{2}{|c|}{ Consensus document } & \multicolumn{2}{|c|}{ Consensus document } \\
\hline Driving licence group & Private & Commercial & Private & Commercial & Private & Commercial & Private & Commercial & Private & Commercial \\
\hline \multicolumn{11}{|l|}{ ICD } \\
\hline Secondary prevention & 3 months & NA & 6 months & NA & $\begin{array}{c}1 \text { week post } \\
\text { implant and } 3 \\
\text { months after last } \\
\text { SVT episode } \\
\text { without impaired } \\
\text { consciousness or } 6 \\
\text { months if syncopal } \\
\text { VT/VF. } \\
\end{array}$ & NA & $\begin{array}{l}6 \text { month after } \\
\text { CA or } 2 \text { weeks } \\
\text { after implant } \\
\text { (whichever } \\
\text { the longest) }\end{array}$ & NA & 6 months & NA \\
\hline Primary prevention & 4 weeks & NA & 1 week & NA & 4 weeks & $\begin{array}{c}\text { NA (but may drive if } \\
\text { risk of events < } \\
1 \% / \text { year) }\end{array}$ & 2 weeks & NA & 1 week & NA \\
\hline Generator change & 1 week & & & & & $>>>$ & 2 weeks & & 1 week & \\
\hline Lead revision & 4 weeks & & & & & 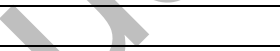 & & & 1 week & \\
\hline $\begin{array}{l}\text { Primary indication, } \\
\text { patient refusing device }\end{array}$ & NR & NA & & & & & & & & \\
\hline $\begin{array}{l}\text { Secondary indication, } \\
\text { patient refusing device }\end{array}$ & 7 months & NA & & & & & & & & \\
\hline Appropriate therapy & 3 months & & 6 months & & $\begin{array}{l}6 \text { months (if loss of } \\
\text { consciousness or } \\
\text { disabling } \\
\text { symptoms. ATP } \\
\text { included) }\end{array}$ & & $\begin{array}{l}4 \text { weeks (if } \\
\text { symptoms of } \\
\text { hemodynamic } \\
\text { compromise }\end{array}$ & & 3 months & \\
\hline Inappropriate therapy & $\begin{array}{l}\text { Until measures to } \\
\text { prevent subsequent } \\
\text { inappropriate } \\
\text { therapy are taken }\end{array}$ & & 6 months & & & & & & $\begin{array}{c}\text { NR } \\
\text { (3 months if } \\
\text { syncope) }\end{array}$ & \\
\hline \multicolumn{11}{|l|}{ PACEMAKER } \\
\hline Insertion & $\begin{array}{c}\text { NR } \\
\text { Wound healing and } \\
\text { PM functioning has } \\
\text { to be confirmed }\end{array}$ & $\begin{array}{c}2 \text { weeks and } \\
\text { wound healing } \\
\text { and PM } \\
\text { functioning has to } \\
\text { be confirmed } \\
\end{array}$ & $\begin{array}{l}\text { NR (1 week } \\
\text { if } \\
\text { pacemaker } \\
\text { dependent) }\end{array}$ & $\begin{array}{l}\text { NR (4 weeks if } \\
\text { pacemaker } \\
\text { dependent) }\end{array}$ & 1 week & 4 weeks & 2 weeks & 4 weeks & 1 week & $\begin{array}{l}\text { NA until PM } \\
\text { integrity is } \\
\text { ascertained }\end{array}$ \\
\hline Generator change & $\begin{array}{c}\text { NR } \\
\text { Wound healing and } \\
\text { PM functioning has } \\
\text { to be confirmed }\end{array}$ & $\begin{array}{c}2 \text { weeks and } \\
\text { wound healing } \\
\text { and PM } \\
\text { functioning has to } \\
\text { be confirmed }\end{array}$ & & & & & & & & \\
\hline Lead revision & & $x^{2}$ & & & & & & & & \\
\hline
\end{tabular}

Table 2: Driving restrictions after implantation of cardiac implantable electronic devices in 5 countries around the world.

References (36, 50, 88-90) 


\begin{tabular}{|c|c|c|}
\hline & $\begin{array}{c}\text { Private } \\
\end{array}$ & Commercial \\
\hline EU & $\begin{array}{l}\text { Ordinary motor cycles, cars and other small } \\
\text { vehicles with or without a trailer }\end{array}$ & $\begin{array}{c}\text { Vehicles over } 3.5 \text { metric tons or passenger- } \\
\text { carrying vehicles exceeding eight seats excluding } \\
\text { the driver }\end{array}$ \\
\hline Austria & Similar to EU & Similar to EU \\
\hline Belgium & Similar to EU & Similar to EU \\
\hline Denmark & Similar to EU & Similar to EU \\
\hline France & Similar to EU & Similar to EU \\
\hline Germany & Similar to EU & Similar to EU \\
\hline Italy & Similar to EU & Similar to EU \\
\hline Netherlands & Similar to EU & Similar to EU \\
\hline Norway & Similar to EU & Similar to EU \\
\hline Spain & Similar to EU & Similar to EU \\
\hline Sweden & Similar to EU & Similar to EU \\
\hline UK & Similar to EU & Similar to EU \\
\hline US & $\begin{array}{l}\text { Drivers who do not meet commercial drivers' } \\
\text { definition }\end{array}$ & $\begin{array}{l}\text { Vehicles weighing }>26,001 \text { pounds; truck with } \\
\text { double/triple trailers or carrying hazardous } \\
\text { materials; passenger vehicles designed to carry } \\
>16 \text { passengers including the driver }\end{array}$ \\
\hline Canada & $\begin{array}{l}\text { Driver who drives }<36,000 \mathrm{~km} / \text { year or spends }< \\
720 \mathrm{~h} / \text { year behind the wheel and drives a vehicle } \\
<11 \text { tons and does not earn a living from driving }\end{array}$ & $\begin{array}{c}\text { Drivers who do not meet private drivers' } \\
\text { definition }\end{array}$ \\
\hline Australia & $\begin{array}{c}\text { Cars }<4.5 \text { tons and seating up to } 12 \text { adults } \\
\text { including the driver or light rigid vehicle between } \\
4.5 \text { and } 8 \text { tons (or } 9 \text { tons if having a trailer) }\end{array}$ & $\begin{array}{l}\text { Any vehicle }>8 \text { tons (or } 9 \text { tons with a trailer), } \\
\text { carrying public passengers for hire or reward, } \\
\text { carrying dangerous goods or working as a driver } \\
\text { instructor }\end{array}$ \\
\hline Japan & $\begin{array}{c}\text { Driver of ordinary motor cycles, cars and other } \\
\text { small vehicles with or without a trailer and does } \\
\text { not earn a living from driving }\end{array}$ & $\begin{array}{l}\text { Drivers who drive for a commercial operation } \\
\text { (including taxi, bus, private ambulance) }\end{array}$ \\
\hline
\end{tabular}

Table 3: Driving licence categories in 16 countries.

References (33, 50, 75-79, 81-86, 89-94) 